\title{
Immunological Aspect of Radiation-Induced Pneumonitis, Current Treatment Strategies, and Future Prospects
}

\author{
Anup Kainthola', Teena Haritwal', Mrinialini Tiwari', Noopur Gupta', Suhel Parvez ${ }^{2}$, \\ Manisha Tiwari ${ }^{3}$, Hrideysh Prakash ${ }^{4}$ and Paban K. Agrawala ${ }^{1 *}$ \\ 'Department of Radiation Genetics and Epigenetics, Institute of Nuclear Medicine and Allied Sciences, Delhi, India, \\ ${ }^{2}$ Department of Toxicology, School of Chemical and Life Sciences, Jamia Hamdard University, New Delhi, India, ${ }^{3}$ Ambedkar \\ Center for Biomedical Research, University of Delhi, Delhi, India, ${ }^{4}$ School of Life Sciences, Science complex, University of \\ Hyderabad, Hyderabad, India
}

OPEN ACCESS

Edited by:

Jixin Zhong,

Case Western Reserve

University, USA

Reviewed by:

Luz Pamela Blanco,

National Institute of

Health, USA

Patrick Geraghty,

SUNY Downstate Medical

Center, USA

Zhe Wang,

Heidelberg University,

Germany

Xun Liu,

Brigham and Women's

Hospital, USA

*Correspondence:

Paban K. Agrawala

paban@inmas.drdo.in

Specialty section:

This article was submitted

to Inflammation,

a section of the journal

Frontiers in Immunology

Received: 07 December 2016

Accepted: 12 April 2017

Published: 02 May 2017

Citation:

Kainthola A, Haritwal T, Tiwari M,

Gupta N, Parvez S, Tiwari M, Prakash H and Agrawala PK (2017) Immunological Aspect of Radiation-

Induced Pneumonitis, Current

Treatment Strategies,

and Future Prospects.

Front. Immunol. 8:506.

doi: 10.3389/fimmu.2017.00506
Delivery of high doses of radiation to thoracic region, particularly with non-small cell lung cancer patients, becomes difficult due to subsequent complications arising in the lungs of the patient. Radiation-induced pneumonitis is an early event evident in most radiation exposed patients observed within 2-4 months of treatment and leading to fibrosis later. Several cytokines and inflammatory molecules interplay in the vicinity of the tissue developing radiation injury leading to pneumonitis and fibrosis. While certain cytokines may be exploited as biomarkers, they also appear to be a potent target of intervention at transcriptional level. Initiation and progression of pneumonitis and fibrosis thus are dynamic processes arising after few months to year after irradiation of the lung tissue. Currently, available treatment strategies are challenged by the major dose limiting complications that curtails success of the treatment as well as well being of the patient's future life. Several approaches have been in practice while many other are still being explored to overcome such complications. The current review gives a brief account of the immunological aspects, existing management practices, and suggests possible futuristic approaches.

Keywords: radiation pneumonitis, fibrosis, lungs, inflammation, HDAC inhibitor

\section{INTRODUCTION}

Majority of cancer treatment involves the use of radiation, at least at times. Radiotherapy procedures involving lungs, as in the case of non-small cell lung cancer (NSCLC) and some others, face a major limitation in delivering higher radiation doses because of the concerns of later lung toxicities experienced in the form of pneumonitis and fibrosis. At early stages, the local inflammation and alterations in cytokine production, lead to pneumonitis development. In the following sections, the biomarkers of radiation-induced pneumonitis and current modalities under practice to overcome complications like radiation-induced pneumonitis available in literature will be discussed. Further, besides the recent progresses in developing modalities to reduce or mitigate radiation pneumonitis, the possibility of using HDAC inhibitors for the same will be highlighted.

\section{IMMUNOLOGY OF RADIATION-MEDIATED LUNG INJURY}

Lymphocytes which perform diverse function in rendering immunity include $\mathrm{T}$ cells, B cells, and natural killer (NK) cells. T cells are known to act in antigen recognition and its processing while 
$\mathrm{B}$ cells are responsible for the production of cytokines and antibodies. NK cells can induce direct cell-mediated killing of virusinfected cells and tumor cells. This section focuses on the role of $\mathrm{T}$ lymphocytes and certain cytokines in the vicinity of tissue injured due to radiation exposure. In case of pulmonary tissues, $\gamma \delta$ T cells reside in the subepithelium of alveolar and non-alveolar regions (1). As mentioned earlier, they play a key role in modulation of immune response against pathogens and allergens $(2,3)$. This is accepted now that lymphocyte subsets have distinct radiosensitivities, with immunosuppressive $\mathrm{T}$ regulatory cells being more radioresistant (4). Macrophages are relatively radioresistant and they are found in increased concentration in the vicinity of tumor stroma. This owes to their survival associated with recruitment (5-7). Simonian et al. explained the mechanism by which $\gamma \delta$ T cells suppresses $C D 4^{+}$cell recruitment by secreting regulatory IL-22 and help preventing progression of fibrosis (8). Different subsets of $\mathrm{T}$ cells perform specific functions. Certain studies have shown that T helper- 9 subset may have a direct role in the asthma (9). In addition to the Th9, the Th22 and TFH cells have been investigated for their possible role in host defense against viruses and bacteria in the lung $(10,11)$.

In general, fractionated radiation therapy is considered immunosuppressive. Ceramide pathway activation occurs as a result of more than 10 Gy per fraction radiation in a sequential manner (12). Pulmonary fibrosis in lung cancer patients presents a picture where recovery of injury at specific tissue can be understood. It is observed that about $15 \%$ of patients receiving high-dose radiation for therapy of lung cancer exhibit pneumonitis (13).

Experiments performed under controlled environment in vitro have reported that cytokines such as transforming growth factor $\beta$ (TGF- $\beta$ ) and interleukin-4 (IL-4) stimulate collagen synthesis in fibroblasts (14). While there are published evidences to establish the fact that certain cytokines like TGF- $\beta 1$ play a role in progression of radiation-mediated fibrosis (15), IL-4, and IL-13 type 2 helper T cell (Th2) cytokines, in association with TGF- $\beta$ are also known to facilitate fibrosis (16).

Investigators have proved that (17-19) elevation of TGF- $\beta$ late during radiotherapy is associated with risk of pulmonary toxicity. To gauge the changes in levels of IL- $1 \alpha$ and IL-6, a study was conducted by Chen et al. (20). It was noticeable that except TNF- $\alpha$, there was a consistently elevated level of IL- $1 \alpha$ and IL-6 prior to and throughout treatment in patients having radiation pneumonitis. However, levels of E selectin, L selectin, TGF- $\beta 1$, and basic fibroblast growth factor (bFGF) did show some variation but were not correlated with radiation pneumonitis. Investigators correlated their study with Rübe et al. who observed different results as indication of correlation between radiationinduced pneumonitis in patients with NSCLC and serum levels of IL- 6 or TGF- $\beta$ prior to and after radiotherapy (21). TNF- $\alpha$, is known to have its role in fibrosis development (22) and leads to TGF- $\beta 1$ induction. Hence, it becomes a target molecule to check the progression of fibrosis.

Büttner et al. (14) in a similar study aimed to document the presence of IL-4 during the development of post-irradiation lung fibrosis. Male Fischer rats were irradiated with a single dose of 20 Gy and IL-4 expression in the irradiated lungs were monitored for a period of 3 months. IL- 4 gene transcription as well as synthesis was increased in the irradiated lungs reaching a plateau concentration within 3 weeks after irradiation. Further, they showed a substantial IL-4 production by macrophages during development of post-irradiation lung fibrosis. These results suggest a correlation between local IL-4 protein expression and the development of radiation-induced pulmonary fibrosis (RIPF). With this kind of results, it was further noticed that IL-4 mRNA levels and the IL-4 protein levels do not closely correlate in the late stages of the development of pulmonary fibrosis (14). The results were in line with the other studies and could infer that it was an intracellular storage of IL-4 protein similar to the reported documentation of TNF- $\alpha$ in mast cells $(23,24)$. Regarding IL- $1 \beta$, it is directly upregulated by radiation and activates other inflammation-related molecules such as the matrix metalloproteinases (MMPs), enzymes that regulate or degrade extracellular matrix components (25).

A similar study (26) was conducted to observe the changes of IL-6 during radiation pneumonitis, along with combined covariations of IL- 6 and IL-10. However, in case of lung cancer radiotherapy, Crohns et al. found that after 3 months higher than baseline levels of IL-8 in serum and bronchoalveolar lavage (BAL) were associated with shorter survival (27). They could not establish any association between survival and the levels of TNF- $\alpha$, IL-1 $\beta$, IL-6, IL-12, and IL-18. A study conducted by Wilson et al. demonstrated that the severity of lung injury in mice was significantly decreased after mice IL-17A gene knockout, which proves the potent role of IL-17A in inflammation and fibrosis (28).

Haiping et al. moved a step ahead when he conducted an experiment to investigate whether radiation-induced pneumonitis in the mouse-irradiated lung could be prevented by recombinant adenovirus-mediated soluble TGF- $\beta$ type II receptor gene therapy. They basically used an adenoviral vector expressing a soluble TGF$\beta$ type II receptor (AdCMVsTbR), which could bind to TGF- $\beta$ and then block the TGF- $\beta$ receptor-mediated signal transduction. After 4 weeks of irradiation, mice were killed and the concentration of TGF- $\beta 1$ in the serum and BALF were measured. The researchers found that following thoracic irradiation with a single dose of 9 Gy, radiation-induced TGF- $\beta 1$ release in the serum reached the first peak concentration at $12 \mathrm{~h}$ and then declined. They concluded that TGF- $\beta$ plays a critical role in the pathogenesis of radiationinduced pneumonitis and that the interaction of TGF- $\beta$ with its receptor is a promising prophylactic target (29).

Brickey et al. (30) carried out an investigation on the role of innate immune regulators like toll-like receptors in injury sustained from irradiation. In their study, they emphasized on the role of MyD88 in regulating innate immunity and nuclear factor kappa-B (NF- $\mathrm{B})$-activated responses. The group examined the immune cells and factors during acute pneumonitic and fibrotic phases in MyD88-deficient animals receiving thoracic gamma $(\gamma)$-irradiation. Brickey et al. found that MyD88 supports survival from radiation-induced injury through the regulation of inflammatory factors that aid in recovery from irradiation $(30,31)$. Also, the absence of MyD88 resulted in unresolved pulmonary infiltrate and enhanced collagen deposition plus elevated Th2 cytokines in long-term survivors of irradiation.

These results summarily demonstrated that post-irradiation in lungs, MyD88 is important for regulating non-infectious 
inflammatory processes to promote tissue regeneration. Most notably, this group observed initially persisting cellular infiltrate and collagen deposition in the $\mathrm{MyD} 88^{-/-}$survivors of radiation lung injury in the context of diminished abundance of proinflammatory mRNA (i.e., Il6, Ccl2/Mcp1). This observation was correlated with results of other similar investigations $(32,33)$ who observed exacerbated lung injury and inflammatory cell accumulation in MyD88 ${ }^{-/-}$mice due to infection with pulmonary specific pathogens.

More recently, Wang et al. investigated the expressions of IL-17A in different phases of radiation-induced lung injury and the effect of dexamethasone. In their study, they observed that IL-17A expression was appreciable at 1 week, peaked at 4 weeks, and subsequently declined at 8 weeks after irradiation. However, on administering the drug of their choice, i.e., dexamethasone, IL-17A was reduced after application at all the observation periods. It was evident from this study that IL-17A plays an important role in the process of radiation-induced lung injury (34). The researchers further aligned their observation by comparing their study with other investigators who proved that IL-17A was significantly increased in a variety of chronic inflammatory disease models $(35,36)$.

Finally, a generalized study needs to be mentioned here which aimed at exploring lung inflammation leading to pulmonary toxicity after radiotherapy in patients with NSCLC. This study by Shankar et al. showed that inflammatory cytokines were induced in NSCLC patients during and after radiotherapy. They recorded changes in levels of IP-10, MCP-1, eotaxin, IL-6, and TIMP-1 and could correlate it with higher-grade toxicity. Investigators reported that inflammatory cytokines were induced in patients with NSCLC both during and after radiotherapy and concentrations of IL-6, MCP-1, MCP-3, and IP-10 correlated with the mean lung dose (MLD) (37). This particular study and so far quoted studies suggest the induction of different inflammatory cytokines as a result of radiation exposure which develops into radiation pneumonitis. These particular cytokines play a specific role in initiation and development of fibrosis and pneumonitis. Not only can they be targeted as an intervention point, but also may be exploited as biomarker for early detection of radiation-induced lung injury. Figure 1 is a schematic presentation of some important signaling pathways playing role in radiation-induced pneumonitis.

\section{PREDICTORS FOR RADIATION-INDUCED LUNG TOXICITY}

Radiation-induced pneumonitis is characterized mainly by increased infiltration of neutrophils and macrophages, enhanced activity of E selectin, tumor necrosis factor (TNF), and monocyte chemotactic factors. The inflammatory condition in the local region results into acute inflammation leads to radiation-induced fibrosis, if untreated. Understanding of molecular and cellular processes helps in defining biomarkers that identifies the risk for developing radiation pneumonitis. For preventive measures and to reduce the severity of radiation-mediated injury, it becomes import to identify and define certain biomarkers and predictors of radiation-induced pneumonitis.

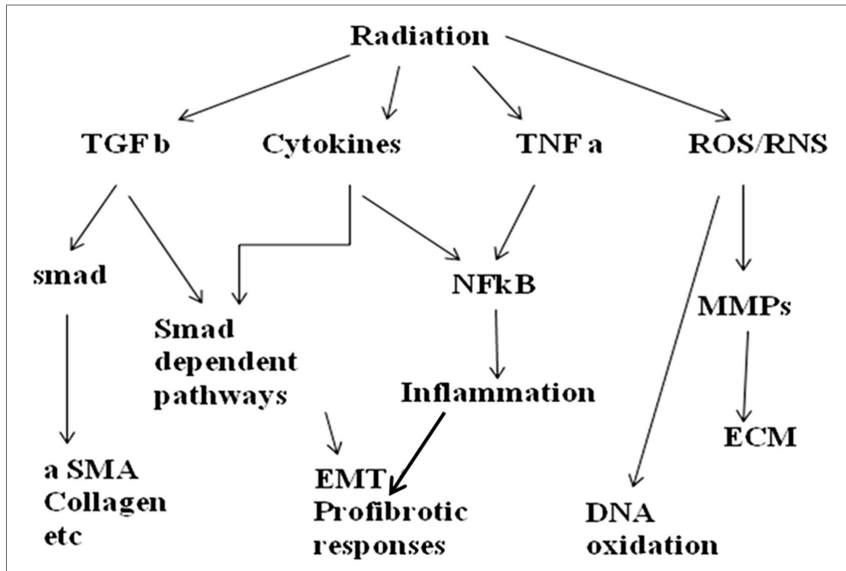

FIGURE 1 | Schematic diagram showing major signaling pathways involved in radiation pneumonitis.

\section{Matrix Metalloproteinases (MMPs)}

Matrix metalloproteinases, a family of proteolytic enzymes involved in the turnover and remodeling of basement membrane and extracellular matrix proteins, can be considered as potential predictor of lung tissue injury (38). Gelatinase B and type IV collagenase degrades macromolecules like fibronectin, collagen (type IV), laminin, and elastase and in the lung interstitial matrix. Tissue inhibitors of metalloproteinases are generally required to regulate the activity of MMP and form physiologically irreversible complexes. One of the MMPs, MMP-9, is produced by different cell types like antigen-presenting cells, macrophages, and blood cells-like eosinophils and neutrophils, and holds the capacity to digest basement membrane. It would be too early to reach to the conclusion that MMPs realistically and evidently correlate with the occurrence of radiation-induced pneumonitis. Measurement of MMP-3 and MMP-9 were observed not to correlate with radiation fibrosis (39). Although the levels of certain MMPs increase during radiation lung injury (40) the role of these molecules still remains unclear.

\section{Transforming Growth Factor}

Transforming growth factor $\alpha$ is a protein coded by the TGFA gene in humans and is a member of epidermal growth factor having mitogenic properties. TGF- $\alpha$ is known to induce phenotypic modulation of human lung fibroblasts to myofibroblasts $(41,42)$ and is a potent stimulator of collagen synthesis $(43)$. It is reported that TGF- $\alpha$ gene expression increased at 1-14 days after radiation therapy simultaneous to the changes in fibroblast gene expression of collagens I/III/IV and fibronectin $(44,45)$. As discussed earlier that TGF- $\alpha$ is produced by different cell types, pneumocytes, and also fibroblasts. The constant abnormal level by the end of the treatment indicates the level of injury in the local tissue. As the biomarker for radiation pneumonitis, plasma TGF- $\alpha 1$ levels have been successfully used for the stratification of patients into low-, intermediate-, and high-risk groups $(44,45)$. However, lung cancer patients often have elevated plasma TGF- $\alpha 1$ level because of tumor TGF- $\alpha 1$ production 
(46). A decrease in TGF- $\alpha 1$ expression may therefore occur as the tumor regresses. Serial plasma TGF- $\alpha 1$ determination and dose-volume relationships are needed to identify patients at low risk (47). TGF- $\alpha 1$ is secreted as a biologically inactive complex that is activated by various elements such as matrix proteins and proteases in response to tissue damage $(48,49)$. In an experimental setup, where radiation-sensitive and non-sensitive strains were produced, it was observed that TGF- $\alpha$ and latent TGF- $\beta 1$ activation occurred by DNA-damaging agents and free radicals produced due to radiation therapy (50). This activation of TGF- $\alpha$ and latent TGF- $\beta 1$ in plasma is suggestive of initiation of radiation pneumonitis after radiation therapy. Notable reduction in the fibrotic proliferation was observed in rats treated with an adenoviral-mediated soluble TGF- $\alpha$ type II receptor (51). The predictive value for the initiation and progression of interstitial pneumonitis was $90 \%$ or more when pre-transplantation plasma TGF- $\beta 1$ levels were more than two SDs above the mean established in the controls. In an investigation, absolute TGF- $\beta$ plasma levels did not differ between the groups of patients without or with pneumonitis. The patients who developed pneumonitis clearly showed increase in TGF- $\beta$ levels in the middle of the radiation therapy course relative to their pretreatment levels while TGF- $\beta$ plasma levels of patients who did not develop pneumonitis decreased over the radiation treatment. The difference in the relative TGF- $\beta$ dynamics between the groups reached marginal significance in the third week of the treatment but weakened toward the end of the radiation therapy course. Based on the test's ability to yield more accurate estimate of complication probability in an individual patient compared to empirically expected probability in similar group of patients, the utility of TGF- $\beta$ testing was evaluated at each radiation therapy week. The accuracy of prediction deteriorated at later time points (weeks 4-6) rendering the end-radiation therapy ratios without predictive power (52). The predictive value of TGF- $\beta 1$ on lung toxicity in patients with advanced breast cancer treated by high-dose chemotherapy and autologous bone marrow transplantation has been assessed and documented earlier (53). Hence, TGF- $\beta$ is regarded useful not only as a marker for pneumonitis and fibrosis but also predicting an individual patient's risk for developing late radiation-induced normal tissue injury. To establish a direct correlation of TGF- $\beta 1$ with the occurrence of pneumonitis, an observation was made on patients. Then, $80 \%$ of patients who developed signs and/or symptoms of pulmonary injury consistent with pneumonitis had persistently elevated plasma TGF- $\beta$ levels by the end of therapy. On the contrast, three patients who did not showed sign and/or symptoms of pneumonitis, plasma TGF- $\beta$ levels normalized by the end of radiotherapy. This finding appeared to be independent of the volume of irradiated lung. The investigators thus concluded that their preliminary results suggested that the failure of plasma TGF levels to return to normal, before the completion of radiotherapy with curative intent for lung cancer, might be predictive for an increased risk of pneumonitis development. However, apart of the pneumonitis, it was hypothesized that TGF- $\beta$ appears to be produced either directly or indirectly by some NSCLC, and declining plasma levels during therapy may be indicative of tumor cell death (17). Early circulatory chemokines thus provide a good predictive measure to identify the individual at risk of developing radiation pneumonitis.

\section{IL-6}

IL-1 and IL- 6 are cytokines responsible for mediating inflammatory responses (54). TNF- $\alpha$ is known to promote the growth of fibroblasts and stimulate the synthesis and release of cytokines such as IL- 6 and IL-1. The cascade effect of cytokines follows after that (55). IL-6 synthesized and secreted by various cells in the lung parenchyma is a pleiotropic cytokine that regulates immune responses and inflammatory response by inducing hepatocytes and lung fibroblasts to release acute phase proteins $(56,57)$. Hence, understandably, IL-6 levels in the serum can be used to judge the inflammatory state of the lung. Serial plasma specimen analysis for circulating cytokine changes prior to, during and up to 12 weeks after radiation in 24 patients diagnosed with radiation pneumonitis was done to ascertain cytokine levels after thoracic radiotherapy. Assessment of IL-1 $\alpha$, IL-6, MCP-1, E selectin, L selectin, TGF- $\beta 1$, and bFGF during the progression of disease revealed some promising information. However, no significant correlation between variation in pattern of changes of MCP-1, E selectin, L selectin, TGF- $\beta 1$, and bFGF and radiation pneumonitis could be established. The study summarized as high pretreatment plasma levels of IL- 6 predisposed patients to the risk of radiation pneumonitis and therefore pretreatment IL-6 level may serve as a predictor for radiation pneumonitis. Patients with radiation pneumonitis demonstrated higher circulating levels of IL-6 during and immediately after thoracic radiotherapy. However, the mechanism for IL-6 involvement in radiation pneumonitis warrants further investigation (58). Variation in IL-6 was also observed by a Chinese group (59), where it increased after RT. However, in the same study, a decrease in IL-10 was also observed, which indicates that RT induces changes in IL-6 and IL-10.

\section{Platelet-Derived Growth Factor (PDGF)}

Platelet-derived growth factor has importance in showing profibrotic activities. Many fibrogenic mediators like IL-1, TNF- $\alpha$, bFGF, and thrombin are known to accelerate and take part in the fibrotic process. PDGF further has role in proliferation and migration of myofibroblasts during fibrosis. In a study, it was observed that irradiation of the endothelial cells or human cancer cell lines like A549 cells induced phosphorylation of PDGFR in fibroblasts at 6 and $72 \mathrm{~h}$ after irradiation resulting in activation of PDGFR and subsequent infiltration of myofibroblasts in the local area. Thus activated fibrogenic mediators become an important biomarker for an individual at risk of radiation-induced pneumonitis during 6 and $72 \mathrm{~h}$ after irradiation. Also, all PDGF isoforms were significantly upregulated after $10 \mathrm{~Gy}$ radiation in human lung microvascular endothelial cells $(\mathrm{P}<\mathrm{M} 0.02)$ and persisted up to $72 \mathrm{~h}$ after irradiation (60). Fibrotic activity of TGF- $\alpha$ and bFGF depends on PDGF profibrotic activity. Radiation-induced expression of PDGF and phosphorylation of PDGF receptors persist at least till $72 \mathrm{~h}$ after irradiation and till late phase in radiation-induced fibrosis.

The occurrence and severance of radiation lung toxicity is also dependent upon different factors such as age, smoking habits, 
location of tumor, and lung dosimetric factors. Out of these general factors, the lung dosimetric factors and the lung dose-volume histogram (DVH)-based normal tissue complication probability (NTCP) models have been extensively studied. Point parameters such as volumes $(V)$ receiving a $V 30, V 20, V 13, V 5$, or other dose, the dose to a certain portion of the lung volume (such as D30), effective lung volume, and MLDs are of immense importance. Investigation group of Kong and coworkers have provided an extensive review on these parameters (61-63). Though none have optimal predictive power (for individuals) for routine clinical use, various NTCP models and many DVH parameters are still considered as predictive of the risk of radiation pneumonitis for populations of patients. Rather the investigators found the predictive capacity to be individually varying. Precisely, they quoted that statistically significant association or description of complication rates for populations of patients is not equivalent to a good predictor of toxicity for each individual patient. They further elaborated the conclusion with example. $V 13, V 20$, and MLD were all predictive of radiation pneumonitis, but they all had a similar suboptimal predictive ability for grade 2 and higher RIL (64). If cut-offs are 30\% for V20, 20 Gy for MLD, and 10\% for NTCP, these factors have positive-predictive values of only $50-71 \%$ and negative-predictive values of $85-89 \%(61,62,64)$. The cut off values used in this study generated reasonable (80-85\%) certainty of identifying low-risk patients but unacceptable (50-70\%) low-sensitivity and positive-predictive values. Figure 2 depicts predictors of radiation-induced pneumonitis and fibrosis.

\section{Dosimetric Parameters [Pretreatment Performance Status and Forced Expiratory Volume (FEV)]}

The $V$-dose parameter is defined as the percentage of computed tomography (CT)-defined total lung volume minus the PTV receiving a higher or equal dose compared to the threshold dose (e.g., 20 or 25 Gy). The MLD is defined as the average dose of the CT-defined total lung volume.

A set of samples were reviewed in a study to identify factors that may predict for severe radiation pneumonitis or pneumonopathy (RP). In 144 evaluable patients, 12 (8.3\%) experienced severe RP. The most significant factor predicting for severe RP was performance status $(p<0.003)$. The risk of severe RP was $16 \%$ for PS- 1 patients vs. $2 \%$ for PS- 0 patients. On the basis of gender, women were found to be significantly more susceptible to develop severe RP than men $(p<0.01)$. FEV of the lung in $1 \mathrm{~s}$ (FEV1) was also significant $(p<0.03)$. To find the possibility of radiation dose to be used as biomarker for radiation pneumonitis, median radiation dose and median initial radiation were assessed. Median radiation dose was 59.2 Gy and median initial radiation field size was $228 \mathrm{~cm}^{2}$. Neither radiotherapy factor predicted for RP. The study also investigated chemotherapy drugs and schedule which also were not found significant predictors for severe radiation pneumonitis. Evidently, it was concluded that pretreatment performance status, gender, and FEV1 are significant predictors of severe radiation pneumonitis (65).

There are further comprehensive and reliable studies conducted to establish effective volume ( $\left.V_{\text {eff }}\right)$, total lung volume mean dose, and location of tumor as potential predictors for radiation pneumonitis. With an aim of identifying a clinically relevant and available parameter upon which to identify NSCLC patients at risk for pneumonitis, univariate analysis was done. The percent of the total lung volume exceeding $20 \mathrm{~Gy}$ (V20), the $V_{\text {eff }}$ and the total lung volume mean dose, and location of the tumor primary (upper versus lower lobes) to be statistically significant relative to the development of $>$ grade 2 pneumonitis. Multivariate analysis was done in the same study which further revealed the $V 20$ to be the single-independent predictor of pneumonitis (66). Complete vetting of the study presented the fact that the $V 20$ from the total lung DVH is a useful parameter easily obtained from most 3D treatment planning systems. Authors could concluded that the $V 20$ may be useful in comparing competing treatment plans to evaluate the risk of pneumonitis and may also be a useful parameter upon which to stratify patients or prospective dose escalation trials. There is strong evidence that both the V20 and the MLD, correlate with the risk of high-grade radiation pneumonitis $(66,67)$. It was concluded by a group of researchers that both the biological and physical risk factors allow better identification of patients at risk for the development of symptomatic radiationinduced lung injury (68).

Several other factors are being investigated for being early biomarkers for pneumonitis. Age, WHO performance status, and tumor locations are potential risk factor for which conflicting evidence has been published and discussed. As mentioned earlier, the range of factors spans from clinical to biochemical/molecular to physical. In one such study, several clinical factors were

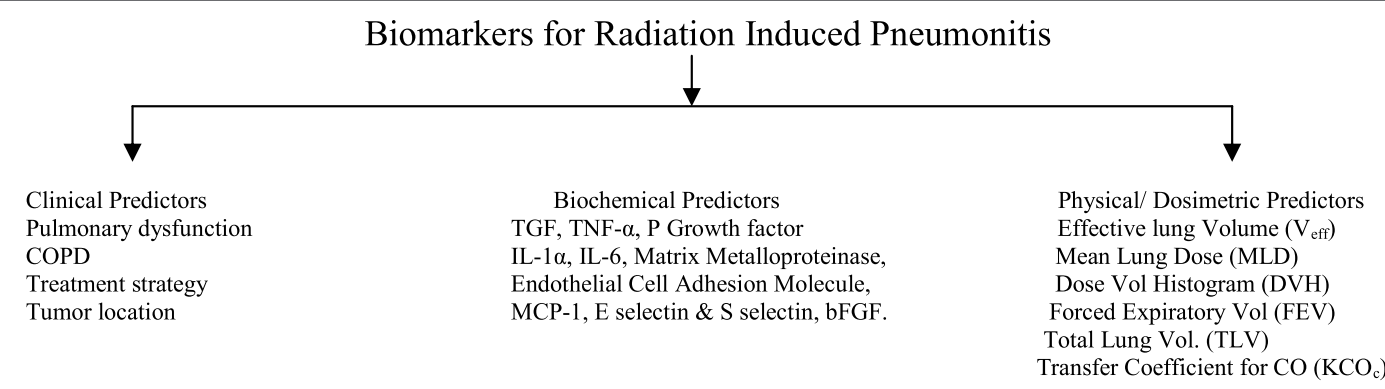

FIGURE 2 | Schematic diagram depicting broad categories of predictors for radiation-induced lung toxicity like pneumonitis and fibrosis. 
investigated. Pulmonary dysfunction before radiation therapy may predispose patients for radiation pneumonitis. Chronic obstructive pulmonary disease (COPD) and impaired lung function measurements have been documented to be associated with radiation-induced lung toxicity $(65,69)$. While in other studies, it was found to have no statistically significant relationship $(70,71)$. Thus there are diverse studies with varying results and with no significant audacity it can be said that these are predictors for radiation-induced lung toxicity. Also, it doesn't apply for every individual.

\section{Dosimetric Predictors}

The records of 160 patients who received radiation therapy for NSCLC were reviewed by Jenkins and Watts to investigate whether multiparametric models that incorporate clinical and physiologic factors have improved accuracy (72). Patients treated with the same dose and with an identical technique were analyzed for dosimetric, pulmonary function, and clinical parameters to determine their ability to predict for the subsequent development of radiation pneumonitis. On univariate analysis, fractional volume of lung receiving >5-20 Gy, absolute volume of lung spared from receiving $>5-15 \mathrm{~Gy}, \mathrm{MLD}$, craniocaudal position of the isocenter, transfer coefficient for carbon monoxide (KCOc), total lung capacity, coadministration of angiotensin-converting enzyme inhibitors (ACEIs), and coadministration of angiotensinreceptor antagonists significantly correlated with the risk of pneumonitis. The authors were able to define a new parameter termed transfer factor spared from receiving $>5$ Gy (TFS5) by combining the absolute volume of lung spared from receiving $>5$ Gy with the KCOc. TFS5 represents a simple parameter that can be used in routine clinical practice to more accurately segregate patients into high- and low-risk groups for developing RP.

Several reports have associated dose-volume metrics with radiation pneumonitis $(66,73)$. Hence, it is clear that radiation pneumonitis is correlated with the dose delivered to a particular fractional volume of the lung.

\section{Single Nucleotide Polymorphism (SNP)}

Single nucleotide polymorphism is a change in which a single base in the DNA differs from the usual base at that position. Researchers conducted a study in which they combined a genome-wide SNPassociated evaluation of inbred strain response with prior linkage and gene expression data to identify genes which influence the fibrotic response to thoracic cavity radiotherapy. It was inferred from the study that on combining genomic approaches, variation were identified within specific genes which function in the tissue response to injury as associated with fibrosis following thoracic irradiation in mice (74).

\section{Other Markers}

Krebs von den Lungen-6 (KL-6) is a mucinous high molecular weight glycoprotein, expressed on type 2 pneumocytes. It is generally regarded as the lung epithelium-specific protein KL-6. Previous studies have suggested that KL-6 is a useful marker for the clinical diagnosis of pneumonitis (75). KL-6 is chemotactic for human fibroblasts and has functional role in fibrotic process. There are published reports suggesting serum KL-6 level reflects the severity of radiation pneumonitis, and the increase ( $>1.5$-fold) was associated with serious radiation pneumonitis that was refractory to steroid therapy (76).

Very few studies were comprehensive enough and to be mentioned where BAL has been tested as a biomarker for clinical pneumonitis.

\section{Reactive Airway Disease}

Reactive airway disease has been identified as a predictive factor for pulmonary toxicity in the patients who were administered the radiation therapy for the treatment of NSCLC (77).

\section{Age}

Studies have shown that patients of 65 years of age or less are more prone to the toxicity than the old age fellows. It is inferred in the study that the reason for this factor is the administration of split course therapy (77).

\section{Normal Tissue Complication Probability (NTCP)}

Computed tomography-based NTCP has been resulted to be the best predictor for the development of the pulmonary symptoms and the NTCP values in patients with pre-RT PFTs have been found to be remarkable (78).

\section{CYFRA 21-1}

Cytokeratin 19 fragment has been considered as marker of apoptosis in including lung cancer and other cancer types. There may be chances that cytokeratin 19 might be released by type II pneumocytes during radiation-induced epithelial cell damage as it is believed to play an important role in apoptosis of type II pneumocytes during radiation-induced lung tissue damage (4).

\section{Intercellular Adhesion Molecule-1 (ICAM-1)}

Intercellular adhesion molecule- 1 belongs to the immunoglobulin group and can be induced by interleukin 1 and TNF. The recruitment and activation of lymphocytes occur in the pathogenesis of radiation-induced pneumonitis. ICAM-1 assists in the leukocyte accumulation due to its adhesive characteristic. The vascular endothelial cells, epithelial cells, and lymphocytes are found etched with the ICAM-1 protein. Studies suggest that on comparing the serum levels of ICAM-1 in healthy individuals to those of cancer patients, it was higher in latter, irrespective of the development of pneumonitis. It has been considered in the findings that radiationinduced pneumonitis may be detected in its early phases with the use of serum ICAM-1 marker, however, monitoring has to be scheduled prior to and throughout the therapy (4).

\section{Central Lung Distance (CLD)}

Central lung distance has been used as a parameter to calculate the percentage of lung irradiated for tangential field. A study for the carcinoma of the breast depicts that the higher CLD amounted to higher irradiation and it suggests CLD as the best method of calculating the irradiation of lungs (79). 


\section{Serum Amyloid}

Serum samples were analyzed in a study from the serum of stages Ib-IV lung cancer patients who developed radiation pneumonitis after a year of radiation therapy. Serum amyloid A was found to be useful auxiliary marker in this finding for predicting the severity of radiation pneumonitis $(80,81)$.

\section{CURRENT TREATMENT STRATEGIES}

Tissue toxicity in lungs and its progression in local/regional areas require specific treatment that is also decided by the physiological status of subject. The most common form of radiation pneumonitis is referred to as bronchiolitis obliterans organizing pneumonia (BOOP) is an inflammatory response of the tissues. Pneumonitis is sub-categorized into organizing pneumonia and secondary organizing pneumonia and the term BOOP is used for the non-idiopathic forms such as radiation therapy BOOP (82) which is characterized by a specific pulmonary lesion with a typical pathologic pattern. The treatment (chemotherapy) for radiation pneumonitis, $\mathrm{BOOP}$, and other radiation-induced lung tissue damage include steroids and diuretics, corticosteroids, other hormones, enzymes, redox regulators, and antioxidants. These molecules have been tested solely or in combination to obtain better prognosis. Criteria which are critical for obtaining recovery and understanding the mode of action of particular drug includes type of drug, doses of drug, period of treatment, time of initiation of drug, and the condition of patient and the irradiation type (whole chest irradiation/chest wall irradiation/ partial irradiation or hypofractionated irradiation).

\section{Steroids and Corticosteroids}

Prednisone, a synthetic corticosteroid drug with immunosuppressant properties, has widely been used in different inflammatory diseases like radiation pneumonitis and some autoimmune diseases but is known to have adverse effects. Prednisone gets converted via hepatic metabolism to prednisolone which improves lung function and minimizes symptoms in radiation-induced pneumonitis and lung tissue toxicity (83). An isoflavonoid, genistein derived from soy products, is also known to inhibit tumor growth by enhancing apoptosis. In mice at non-toxic doses, it protects against radiation-induced lung damage (84).

\section{Pentoxifylline (Trental)}

Pentoxifylline, a methylxanthine derivative, inhibits phosphodiesterase and improves blood flow by increasing erythrocyte and leukocyte flexibility and inhibiting platelet aggregation. Pentoxifylline also stimulates cytokine production. It has shown encouraging results in preventing early and late lung toxicity (85). The current National Comprehensive Cancer Network guidelines recommend concurrent full-dose cisplatin-based chemoradiotherapy regimens. Weekly, docetaxel with conventional radiotherapy resulted in $47 \%$ grade 3 or higher-grade pneumonitis, including $19 \%$ fatal pulmonary toxicity. Pentoxifylline acts as a competitive non-selective phosphodiesterase inhibitor, raises intracellular cyclic adenosine monophosphate (cAMP), activates cAMP-dependent protein kinase, inhibits TNF, and leukotriene synthesis. In the typical conditions like radiation pneumonitis, it has been used as suppressant of innate immunity. In treating breast cancer, chemotherapy concurrent with radiation also plays significant role in developing radiation pneumonitis. Concurrent medication with tamoxifen is among the several factors that culminate into radiation pneumonitis after radiation therapy for breast cancer (86).

\section{Angiotensin-Converting Enzyme Inhibitors}

By causing vasoconstriction, angiotensin increases blood pressure and hence is frequently being used to treat such cases. Angiotensin is an oligopeptide hormone derived from the precursor molecule angiotensinogen, a serum globulin produced in the liver. ACEI causes relaxation of blood vessels and decrease blood volume leading to lower blood pressure. The drug thus is a potent treatment option in conditions like hypertension and elevated blood pressure. ACEIs molecules such as ramipril, perindopril, captopril, and enalapril have been investigated in trial for long.

A study by Wang and coworkers in Texas on whether ACEIs reduce the risk of symptomatic radiation pneumonitis in patients with NSCLC after definitive radiation therapy showed the trend toward reduction in symptomatic radiation pneumonitis among patients taking ACEIs during radiotherapy for NSCLC was not statistically significant. However, this was observed that certain subgroups may benefit from use (i.e., male patients and those receiving low $\mathrm{MLD})(80,81)$.

\section{Adjuvant Systemic Chemotherapy}

Post-operative local/regional radiotherapy (PORT) is generally considered as curative for patients suffering from lung cancer but may cause subsequent inflammatory responses and damage the tissue. Keller et al. (87) conducted a randomized trial of postoperative adjuvant therapy in patients with completely resected stage II or IIIA NSCLC. It was encouraging to know through that adjuvant systemic chemotherapy alone was effective in treatment compared to treatment in combination with radio therapy. Further, concurrent cisplatin-based chemotherapy in addition to PORT did not improve local-regional control or survival compared with PORT alone (87). However, later $(88,89)$, it was reported that effectiveness of adjuvant systemic chemotherapy using different set of molecules like paclitaxel and carboplatin. A 50.4 Gy irradiation in 28 fractions in 6 weeks was done by Bradley et al. (88) followed by a boost of $10.8 \mathrm{~Gy}$ in six fractions for extracapsular nodal extension. Decrease in percentage of survival rates for 1,2 , and 3 years $(86,70$, and $61 \%$, respectively) was observed with no notable difference in survival between stages II and IIIA NSCLC patients. However, the 1-, 2-, and 3-year survival percentage were promising. Feigenberg obtained almost similar results showing survival of 72 and $44 \%$ for 2 and 5 years. The results obtained indicated the synergistic role of adjuvant therapy along with radiotherapy. However, more such studies are warranted to establish adjuvant therapy as a reliable treatment approach. The current National Comprehensive Cancer Network guidelines recommend concurrent full-dose cisplatin-based chemoradiotherapy regimens (90). Onishi et al. (91) investigated on concurrent two-dimensional radiotherapy and weekly docetaxel in the treatment of stage III NSCLC. Although there was a notable local response using docetaxel, the survival rate was not 
significant enough. Weekly, docetaxel with conventional radiotherapy resulted in $47 \%$ grade 3 or higher-grade pneumonitis and 19\% fatal pulmonary toxicity (91).

\section{Indigenous and Traditional Formulations}

It was documented in a study that in comparison to the control group treated only by antibiotic and hormone pulse therapy, Shenqi fuzheng injection (a traditional Chinese medicine) in combination with antibiotics and short-term pulse therapy with hormones had significant effect in improving radiation pneumonitis. The combination improved the radiation-induced lung injury probably by controlling regulation of subsets of T lymphocytes like $\mathrm{CD}^{+}, \mathrm{CD}^{+}$, and $\mathrm{CD} 4^{+} / \mathrm{CD}^{+}$ratio (92). Variable results and limited studies on indigenous drugs, however, have made clinicians reluctant to implicate them as mainstay treatment approach. An indigenous Chinese herbal formulation composed of Liangxue Jiedu Huoxue Decoction formulation comprised of seven herbs namely, Radix astragali, Radix rehmanniae, Cortex moutan, Peach seed, Rhizoma chuanxiong, Fructus forsythia, and Flos carthami, was tested against 100 lung cancer patients scheduled to receive radiotherapy. Not only the lung injuries were limited and improved in treatment group, encouraging results were obtained showing lowered incidence rate of radiation pneumonitis in the treatment group than in the control group receiving only radiotherapy (13.04 and $33.33 \%$, respectively).

\section{Oxygen Therapy}

Although this is not a curative therapy, it is more like a support. The subject undergoing the treatment for lungs-related complications often suffers from breathlessness. The oxygen therapy hence provides an associated support in combination with drugs. It helps in bringing homeostasis of the individuals by leveling the oxygen in the blood and in tissues. However, it has no direct and definite curative properties in terms of inflammation.

\section{Molecular Approaches}

Apart of the chemotherapy, studies have been conducted to ascertain the role of selected genes in modulating the pathologic conditions like RIPF. It was observed that a combined deficiency in both Tlr2 and Tlr4, and not alone, leads to enhanced radiationinduced fibrosis in the C57BL/6 mouse model irradiated with 18 Gy single dose in the thoracic region (93). Research shows the prominent target areas are either the intermediates of the inflammatory pathways or the proteins/enzymes catalyzing biological reactions in-between in the pathogenesis of radiation-induced pneumonitis and fibrosis. Whole process of inflammation leading to radiation-mediated pneumonitis to the severe and chronic form of radiation-induced fibrosis has several potent targets for treatment. The process starts from induction of TGF- $\beta$ by radiation exposure and ends up with unbound snail migrating to the nucleus and repressing E cadherin leading to a mesenchymal-like phenotypic change. In between of these two major events, there are molecules like NRF2, Smad binding element, E cadherin, and GSK3 $\beta$ which can be studied as intervention points. Inhibitors of TGF- $\beta$ RI like SM16 have capability to reduce the severity of radiation-induced lung injury. Protection against development of such injuries has been documented in a rat model (94).
The human TGF $\beta 1$ gene is located on chromosome 19q13.113.39. Associations between the TGF $\beta 1869 \mathrm{C} / \mathrm{T}$ polymorphism and susceptibility to radiation pneumonitis have been documented earlier $(95,96)$. A comprehensive meta-analysis in this regard reports that there was a significant association between TGF $\beta 1$ 869C/T polymorphism and RP susceptibility (OR = 1.77; 95\% CI, 1.27-2.47; $p=0.0007)$. However, the meta-analysis included fewer studies and small ethnic group (97).

A significant survival advantage could be obtained by subsiding $\mathrm{p}$-Smad 2 and $\mathrm{p}$-Smad1 expression. Suppressed expression of $\mathrm{p}$-Smad 2 and $\mathrm{p}$-Smad1 leads to lowered expression of genes responsible in canonical and non-canonical TGF- $\beta$ signaling which results in reduced inflammation and pulmonary fibrosis (98). Investigators have pointed TGF- $\beta /$ Smad as most effective target for development of different inhibitors $(99,100)$. Fluorofenidone [1-(3-fluorophenyl)-5-methyl-2-(1H)-pyridone, AKFPD], a novel pyridone antifibrotic agent, reduced cardiac

TABLE 1 | A summary of current available approaches for radiation pneumonitis management.

\begin{tabular}{ll}
\hline Steroids and & - Mainstay of treatment. \\
corticosteroids & - Administered in primary pneumonitis. \\
& - Oral administration. \\
& - General dose: prednisolone $1 \mathrm{mg} / \mathrm{kg}$ (max $60 \mathrm{mg})$ \\
& for a period of 2 weeks. \\
& - Followed by slow tapering over weeks. \\
& - Incomplete course leads to worsening of symptoms. \\
& - Acts as an anti-inflammatory substance.
\end{tabular}

Angiotensin-converting - Effective in mitigating radiation-induced pneumonitis.

enzyme inhibitors _ - Trails on rats showed variable success.

- Limited efficacy in human subjects. Ex: enalapril.

- Certain conditions like bilateral renal artery stenosis required to be ruled out before initiation of therapy. Blood pressure should be in control.

- Acts by decreasing vascular remodeling and levels of transforming growth factor $\beta$ (TGF- $\beta$ ).

A usual and in practice Once the differentials are ruled out, start the patient approach on prednisolone $1 \mathrm{mg} / \mathrm{kg}$. Continue prednisolone for 2 weeks followed by tapering over 2 weeks. Start pentoxifylline $400 \mathrm{mg}$ thrice daily and enalapril $2.5 \mathrm{mg}$ twice daily for $2-4$ weeks. Consider stopping radiotherapy for a few days if highly symptomatic. If no improvement of symptoms, consider other immunosuppressant-like azathioprine (103).

Molecular approaches Several intermediates that take part in the development of inflammatory response in the lungs can be targeted. Studies have been done on such targets, anti-TGF- $\beta$ type 1 receptor (104), DNA intercalator, inhibits cell proliferation (105), immunoregulation, restoration of the immunological balance and inhibitor of neutrophil elastase (106), decreases collagen deposition and the accumulation of neutrophils. Those are not yet in clinical practice.

Adjuvant systematic - Research shows effectiveness when administered chemotherapy alone.

- Paclitaxel and carboplatin have shown encouraging results.

- National Comprehensive Cancer Network guidelines recommend concurrent full dose.

- Cisplatin-based chemoradiotherapy.

- More studies needed to be done before establishing it as reliable therapy. 
and kidney fibrosis by inhibiting connective tissue growth factor expression $(101,102)$. Cytokines and growth factors thus are oozing as hotspots in checking inflammatory responses. Sivelest at, a neutrophil elastase inhibitor, decreases collagen deposition and aggregation of neutrophil in the tissues of lungs and improves the lung injury be directly interfering in the development of inflammatory response. A brief overview of the current mainstay treatment strategies and strategies under investigation are given in Tables 1 and 2.

\section{FUTURE PROSPECT}

Radiation-induced pneumonitis results from prolonged inflammation caused in the lung tissue due to irradiation. Any approach capable of reducing the inflammatory response or increasing anti-inflammatory molecules thus can be useful in managing radiation-induced pneumonitis. In the recent past, our laboratory has been involved in the development of mitigators of radiation injury, mortality in particular, against whole body irradiation in mice model. As a hypothesis, it was processed that inhibitors of histone deacetylases may be used as mitigators of radiation injury $(116,117)$. We have shown survival advantage against lethal whole body irradiation using trichostatin A (TSA) and epigallocatechin gallate (118), and diallyl disulfide (DAS) (119).
Sulforphane, another dietary HDAC inhibitor, was observed to reduce radiation-induced micronuclei in human peripheral blood lymphocytes $(116,117,120)$. Sodium butyrate $(\mathrm{NaB})$ has been shown to reduce inflammatory cytokine IL-1 (121) and renders neuroprotective effect in mice and similarly a number of HDAC inhibitors having anti-inflammatory properties have been described by Losson et al. (122). Recently, Hu et al. (123) have shown epigenetic regulation of IL- 6 by changing HAT and HDAC dyanamics in a paraquat-induced pulmonary fibrosis model. Yet in another study (124) using peripheral blood mononuclear cells from type II diabetes mellitus (T2DM) patients, designing of future anti-inflammatory drug against T2DM using inhibitors targeted against HDAC 3 has been postulated. The ability of TSA in attenuating bleomycin-induced lung injury in mice has also been demonstrated (125) recently. The HDAC inhibitors used in our studies were found to significantly reduce radiation-induced inflammatory cytokines such as IL- 6, TNF- $\alpha$, TGF- $\beta$ in mice plasma, and serum. For example, TSA effectively reduced IL-6 and TNF- $\alpha$ while enhanced IL-5 level where as DAS reduced IL- 6 and TGF- $\beta$ while increased G-CSF levels. Both the compounds have rendered significant enhancement in survival of lethally irradiated mice and possess no detectable toxicity and hence those compounds further may be explored for their beneficial application in radiotherapy in order to overcome radiation-induced

TABLE 2 | Investigations on application of different treatment regimens for radiation-induced lung complications.

\begin{tabular}{|c|c|c|c|c|c|c|}
\hline S. no. & $\begin{array}{l}\text { Inflammatory } \\
\text { response/ } \\
\text { pathologic } \\
\text { condition }\end{array}$ & Reference & Treatment dose & Radiation dose & Period of course & Drug type \\
\hline 1 & Pneumonitis & $(107)$ & $\begin{array}{l}\text { Adriamycin: } 50 \mathrm{mg} / \mathrm{m}^{2} \text { rechallenged for two further } \\
\text { cycles with no symptoms with steroid cover }\end{array}$ & 15 Gy & 2 months & Steroid \\
\hline 2 & & $(108)$ & Adriamycin: 30 mg/m² & 36 Gy & 3 weeks & Steroids \\
\hline 3 & & $(108)$ & Adriamycin: 30 mg/m² & 59.4 Gy & 6 weeks & Steroids \\
\hline 4 & & $(109)$ & $\begin{array}{l}\text { Paclitaxel: } 175 \mathrm{mg} / \mathrm{m}^{2} \text { rechallenged for one further cycle } \\
\text { with no recurrence after premedication with steroids }\end{array}$ & 43.2 Gy & 12 days & Not specified \\
\hline 5 & & $(110)$ & Intrapleural instillation of $30 \mathrm{mg}$ of adriamycin & 36.5 Gy & 1 month & $\begin{array}{l}\text { Steroids and } \\
\text { diuretics }\end{array}$ \\
\hline 6 & & $(111)$ & Mn porphyrin, MnTE-2-PyP5+ (6 mg/kg/24 h) & 28 Gy & 2 weeks & $\begin{array}{l}\text { Antioxidant and } \\
\text { redox-modulating } \\
\text { Mn porphyrin }\end{array}$ \\
\hline 7 & & $(112)$ & $\begin{array}{l}\text { Genistein diet (10 mg/kg) (in combination } \\
\text { with radiation) }\end{array}$ & 10 Gy & $\begin{array}{l}9 \text { fractions of } 3.1 \text { Gy } \\
\text { over } 30 \text { days }\end{array}$ & Soy isoflavone \\
\hline 8 & & $(113)$ & Omeprazole, esomeprazole, and lansoprazole & $\begin{array}{l}\text { Radiation regimen } \\
\text { was reformulated } \\
\text { after } 50 \text { Gy if } \\
\text { the lesion was } \\
\text { extended }\end{array}$ & 7 days & $\begin{array}{l}\text { Proton pump } \\
\text { inhibitors }\end{array}$ \\
\hline 9 & & $(114)$ & Pentoxifylline (400 mg orally) & 40-84 Gy & 8 weeks & Anticytokine \\
\hline 10 & $\begin{array}{l}\text { Stages I-III } \\
\text { NSCLC after } \\
\text { radiation therapy }\end{array}$ & $(80,81)$ & Angiotensin-converting enzyme inhibitors (ACEIs) & 60 Gy & $\begin{array}{l}\text { During the entire course } \\
\text { of RT (not specified for } \\
\text { individual patient) }\end{array}$ & ACEls \\
\hline 11 & $\begin{array}{l}\text { Radiation } \\
\text { pneumonitis/ } \\
\text { radiation-induced } \\
\text { fibrosis }\end{array}$ & $(115)$ & Cyclooxygenase-2 inhibitor twice daily & 13.5-14.75 Gy & $\begin{array}{l}40 \text { consecutive days } \\
\text { from the day of local } \\
\text { thoracic irradiation } \\
\text { or } 40 \text { or } 80 \text { days later }\end{array}$ & $\begin{array}{l}\text { Celecoxib } \\
\text { (an inducible } \\
\text { enzyme) }\end{array}$ \\
\hline
\end{tabular}


lung injuries including pneumonitis and fibrosis. However, no experimental studies have been performed in this direction so far by our group or others in appropriate model systems for radiation pneumonitis or fibrosis.

\section{AUTHOR CONTRIBUTIONS}

AK, TH, MT, NG, and PA participated in compilation and editing of the manuscript. PA, SP, MT, and HP participated in literature and data collection. All authors read and approved the final version.

\section{REFERENCES}

1. Wands JM, Roark CL, Aydintug MK, Jin N, Hahn YS, Cook L, et al. Distribution and leukocyte contacts of gammadelta $\mathrm{T}$ cells in the lung. J Leukoc Biol (2005) 78(5):1086-96. doi:10.1189/jlb.0505244

2. Born WK, Jin N, Aydintug MK, Wands JM, French JD, Roark CL, et al. Gammadelta T lymphocytes-selectable cells within the innate system? J Clin Immunol (2007) 27(2):133-44. doi:10.1007/s10875-007-9077-z

3. Nanno M, Shiohara T, Yamamoto H, Kawakami K, Ishikawa H. Gammadelta $\mathrm{T}$ cells: fire fighters or fire boosters in the front lines of inflammatory responses. Immunol Rev (2007) 215:103-13. doi:10.1111/j.1600-065X. 2006.00474.x

4. Provatopoulou X, Athanasiou E, Gounaris A. Predictive markers of radiation pneumonitis. Anticancer Res (2008) 28:2421-32.

5. DeNardo DG, Brennan DJ, Rexhepaj E, Ruffell B, Shiao SL, Madden SF, et al. Leukocyte complexity predicts breast cancer survival and functionally regulates response to chemotherapy. Cancer Discov (2011) 1:54-67. doi:10.1158/2159-8274.CD-10-0028

6. Ahn GO, Tseng D, Liao CH, Dorie MJ, Czechowicz A, Brown JM. Inhibition of Mac-1 (CD11b/CD18) enhances tumor response to radiation by reducing myeloid cell recruitment. Proc Natl Acad Sci U S A (2010) 107:8363-8. doi:10.1073/pnas.0911378107

7. Crittenden MR, Cottam B, Savage T, Nguyen C, Newell P, Gough MJ. Expression of NF-kappaB p50 in tumor stroma limits the control of tumors by radiation therapy. PLoS One (2012) 7(6):e39295. doi:10.1371/journal. pone. 0039295

8. Simonian PL, Wehrmann F, Roark CL, Born WK, O’Brien RL, Fontenot AP. Gammadelta T cells protect against lung fibrosis via IL-22. J Exp Med (2010) 207(10):2239-53. doi:10.1084/jem.20100061

9. Aujla SJ, Chan YR, Zheng M, Fei M, Askew DJ, Pociask DA, et al. IL-22 mediates mucosal host defense against Gram-negative bacterial pneumonia. Nat Med (2008) 14(3):275-81. doi:10.1038/nm1710

10. Boyden AW, Legge KL, Waldschmidt TJ. Pulmonary infection with influenza A virus induces site-specific germinal center and $\mathrm{T}$ follicular helper cell responses. PLoS One (2012) 7(7):e40733. doi:10.1371/journal. pone. 0040733

11. Ying X, Su Z, Bie Q, Zhang P, Yang H, Wu Y, et al. Synergistically increased ILC2 and Th9 cells in lung tissue jointly promote the pathological process of asthma in mice. Mol Med Rep (2016) 13(6):5230-40. doi:10.3892/ mmr.2016.5174

12. Garcia-Barros M, Paris F, Cordon-Cardo C, Lyden D, Rafii S, Haimovitz-Friedman A, et al. Tumor response to radiotherapy regulated by endothelial cell apoptosis. Science (2003) 300(5622):1155-9. doi:10.1126/ science. 1082504

13. Abid SH, Malhotra V, Perry MC. Radiation-induced and chemotherapyinduced pulmonary injury. Curr Opin Oncol (2001) 13(4):242-8. doi:10.1097/ 00001622-200107000-00006

14. Büttner C, Skupin A, Reimann T, Rieber EP, Unteregger G, Geyer P, et al. Local production of interleukin-4 during radiation-induced pneumonitis and pulmonary fibrosis in rats: macrophages as a prominent source of interleukin-4. Am J Respir Cell Mol Biol (1997) 17:315-25. doi:10.1165/ ajrcmb.17.3.2279

15. Yarnold J, Brotons MC. Pathogenetic mechanisms in radiation fibrosis. Radiother Oncol (2010) 97:149-61. doi:10.1016/j.radonc.2010.09.002

\section{ACKNOWLEDGMENTS}

The authors extend their sincere thanks to Director, INMAS for providing encouragement and support throughout.

\section{FUNDING}

The work was supported by DRDO, Government of India. TH and NG were supported by DST, India and MT by CSIR, India with student fellowships.

16. Lee CG, Homer RJ, Zhu Z, Lanone S, Wang X, Koteliansky V, et al. Interleukin-13 induces tissue fibrosis by selectively stimulating and activating transforming growth factor beta (1). J Exp Med (2001) 194:809-21. doi:10.1084/jem.194.6.809

17. Anscher MS, Murase T, Prescott DM, Marks LB, Reisenbichler H, Bentel GC, et al. Changes in plasma TGF beta levels during pulmonary radiotherapy as a predictor of the risk of developing radiation pneumonitis. Int J Radiat Oncol Biol Phys (1994) 30(3):671-6. doi:10.1016/0360-3016(92)90954-G

18. Anscher MS, Kong FM, Marks LB, Bentel GC, Jirtle RL. Changes in plasma transforming growth factor beta during radiotherapy and the risk of symptomatic radiation-induced pneumonitis. Int J Radiat Oncol Biol Phys (1997) 370:253-8.

19. Zhao L, Wang L, Ji W, Wang X, Zhu X, Hayman JA, et al. Elevation of plasma TGF- $\beta 1$ during radiation therapy predicts radiation-induced lung toxicity in patients with non-small-cell lung cancer: a combined analysis from Beijing and Michigan. Int J Radiat Oncol Biol Phys (2009) 74:1385-90. doi:10.1016/j. ijrobp.2008.10.065

20. Chen Y, Philip R, Williams J, Hernady E, Smudzin T, Okunieff P. Circulating Il-6 as a predictor of radiation pneumonitis. Int J Radiat Oncol Biol Phys (2001) 49:641-8. doi:10.1016/S0360-3016(00)01445-0

21. Rübe CE, Palm J, Erren M, Fleckenstein J, König J, Remberger K, et al. Cytokine plasma levels: reliable predictors for radiation pneumonitis? PLoS One (2008) 3:e2898. doi:10.1371/journal.pone.0002898

22. Oikonomou N, Harokopos V, Zalevsky J, Valavanis C, Kotanidou A, Szymkowski DE, et al. Soluble TNF mediates the transition from pulmonary inflammation to fibrosis. PLoS One (2006) 1:e108. doi:10.1371/journal. pone. 0000108

23. Gordon JR, Galli SJ. Release of both preformed and newly synthesized tumor necrosis factor alpha (TNF-alpha)/cachectin by mouse mast cells stimulated via the Fc epsilon RI. A mechanism for the sustained action of mast cellderived TNF-alpha during IgE-dependent biological responses. J Exp Med (1991) 174(1):103-7.

24. Beil WJ, Login GR, Gali SJ, Dvorak AM. Ultrastructural immunogold localization of tumor necrosis factor-alpha to the cytoplasmic granules of rat peritoneal mast cells with rapid microwave fixation. J Allergy Clin Immunol (1994) 3:531-6. doi:10.1016/0091-6749(94)90210-0

25. Liu W, Ding I, Chen K, Olschowka J, Xu J, Hu D, et al. Interleukin lbeta (IL1B) signaling is a critical component of radiation-induced skin fibrosis. Radiat Res (2006) 165:181-91. doi:10.1667/RR3478.1

26. Arpin D, Perol D, Blay J-Y, Falchero L, Claude L, Vuillermoz-Blas S, et al. Early variations of circulating interleukin-6 and interleukin-10 levels during thoracic radiotherapy are predictive for radiation pneumonitis. J Clin Oncol (2005) 230:8748-56. doi:10.1200/JCO.2005.01.7145

27. Crohns M, Saarelainen S, Laine S, Poussa T, Alho H, Kellokumpu-Lehtinen P. Cytokines in bronchoalveolar lavage fluid and serum of lung cancer patients during radiotherapy - association of interleukin-8 and VEGF with survival. Cytokine (2010) 50:30-6. doi:10.1016/j.cyto.2009.11.017

28. Wilson MS, Madala SK, Ramalingamet TR, Gochuico BR, Rosas IO, Cheever AW, et al. Bleomycin and IL-1 $\beta$-mediated pulmonary fibrosis is IL-17A dependent. J Exp Med (2010) 207:535-52. doi:10.1084/jem.20092121

29. Haiping Z, Takayama K, Uchino J, Harada A, Adachi Y, Kura S, et al. Prevention of radiation-induced pneumonitis by recombinant adenovirusmediated transferring of soluble TGF-b type II receptor gene. Cancer Gene Ther (2006) 13:864-72. doi:10.1038/sj.cgt.7700959 
30. Brickey WJ, Neuringer I, Walton W, Hua X, Wang EY, Chen Y, et al. Circulating IL-6 as a predictor of radiation pneumonitis. Int J Radiat Oncol Biol Phys (2001) 49:641-8. doi:10.1016/S0360-3016(00)01445-0

31. Brickey WJ, Neuringer IP, Walton W, Hua X, Wang EY, Jha S, et al. MyD88 provides a protective role in long-term radiation-induced lung injury. Int J Radiat Biol (2012) 88(4):335-47. doi:10.3109/09553002.2012.652723

32. Skerrett SJ, Liggitt HD, Hajjar AM, Wilson CB. Cutting edge: myeloid differentiation factor 88 is essential for pulmonary host defense against Pseudomonas aeruginosa but not Staphylococcus aureus. J Immunol (2004) 172:3377-81. doi:10.4049/jimmunol.172.6.3377

33. Bretz C, Gersuk G, Knoblaugh S, Chaudhary N, Randolph-Habecker J, Hackman RC, et al. MyD88 signaling contributes to early pulmonary responses to Aspergillus fumigatus. Infect Immun (2008) 76:952-8. doi:10.1128/ IAI.00927-07

34. Wang LP, Wang YW, Wang BZ, Sun GM, Wang XY, Xu JL. Expression of interleukin-17A in lung tissues of irradiated mice and the influence of dexamethasone. ScientificWorldJournal (2014) 2014:251067. doi:10.1155/ 2014/251067

35. Smith E, Prasad KM, Butcher M, Dobrian A, Kolls JK, Ley K, et al. Blockade of interleukin-17A results in reduced atherosclerosis in apolipoprotein E-deficient mice. Circulation (2010) 121:1746-55. doi:10.1161/ CIRCULATIONAHA.109.924886

36. Mi S, Li Z, Yang HZ, Liu H, Wang JP, Ma YG, et al. Blocking IL-17A promotes the resolution of pulmonary inflammation and fibrosis via TGF$\beta 1$-dependent and -independent mechanisms. JImmunol (2011) 187(6): 3003-14. doi:10.4049/jimmunol.1004081

37. Siva S, MacManus M, Kron T, Best N, Smith J, Lobachevsky P, et al. A pattern of early radiation-induced inflammatory cytokine expression is associated with lung toxicity in patients with non-small cell lung cancer. PLoS One (2014) 9(10):e109560. doi:10.1371/journal.pone.0109560

38. Zucker S, Hymowitz M, Conner C, Zarrabi HM, Hurewitz AN, Matrisian L, et al. Measurement of matrix metalloproteinases and tissue inhibitors of metalloproteinases in blood and tissues. Ann N Y Acad Sci (1999) 878:212-27. doi:10.1111/j.1749-6632.1999.tb07687.x

39. Susskind H, Hymowitz MH, Lau YH, Atkins HL, Hurewitz AN, Valentine ES, et al. Increased plasma levels of matrix metalloproteinase- 9 and tissue inhibitor of metalloproteinase-1 in lung and breast cancer are altered during chest radiotherapy. Int J Radiat Oncol Biol Phys (2003) 56:1161-9. doi:10.1016/ S0360-3016(03)00161-5

40. Araya J, Maruyama M, Sassa K, Fujita T, Hayashi R, Matsui S, et al. Ionizing radiation enhances matrix metalloproteinase-2 production in human lung epithelial cells. Am J Physiol Lung Cell Mol Physiol (2001) 280:30-8.

41. Piguet P-F. Cytokines involved in pulmonary fibrosis. Int Rev Exp Pathol (1993) 34:173-81. doi:10.1016/B978-0-12-364935-5.50017-1

42. Hashimoto S, Gon Y, Takeshita I, Matsumoto K, Maruoka S, Horie T. Transforming growth factor-betal induces phenotypic modulation of human lung fibroblasts to myofibroblast through a c-Jun-NH2-terminal kinase-dependent pathway. Am J Respir Crit Care Med (2001) 163:152-7. doi:10.1164/ajrccm.163.1.2005069

43. Fine A, Goldstein RH. The effect of transforming growth factor-beta on cell proliferation and collagen formation by lung fibroblasts. J Biol Chem (1987) 262:3897-902.

44. Finkelstein JN, Johnson CJ, Baggs R, Rubin P. Early alterations in extracellular matrix and transforming growth factor $\alpha$ gene expression in mouse lung indicative of late radiation fibrosis. Int J Radiat Oncol Biol Phys (1994) 28:621-31. doi:10.1016/0360-3016(94)90187-2

45. Rube CE, Uthe D, Schmid KW, Richter KD, Wessel J, Schuck A, et al. Dose-dependent induction of transforming growth factor beta (TGF-beta) in the lung tissue of fibrosis-prone mice after thoracic irradiation. Int J Radiat Oncol Biol Phys (2000) 47:1033-42. doi:10.1016/S0360-3016(00) 00482-X

46. Kong FM, Washington MK, Jirtle RL, Anscher MS. Plasma transforming growth factor-beta 1 reflects disease status in patients with lung cancer after radiotherapy: a possible tumor marker. Lung Cancer (1996) 16:47-59. doi:10.1016/S0169-5002(96)00611-3

47. Anscher MS, Kong FM. In regard to De Jaeger et al.: significance of plasma transforming growth factor-beta levels in radiotherapy for non-small-cell lung cancer. Int J Radiat Oncol Biol Phys (2005) 61:1276-7. doi:10.1016/j. ijrobp.2004.12.010
48. Assoian RK, Fleurdelys BE, Stevenson HC, Miller PJ, Madtes DK, Raines EW, et al. Expression and secretion of transforming growth factor by activated human macrophages. Proc Natl Acad Sci U S A (1987) 84:6020-4. doi:10.1073/ pnas.84.17.6020

49. Sacco O, Romberger D, Rizzino A, Beckmann JD, Rennard SI, Spurzem JR. Spontaneous production of transforming growth factor-beta 2 by primary cultures of bronchial epithelial cells. JClin Invest (1992) 90:1379-85. doi:10.1172/JCI116004

50. Barcellos-Hoff MH. Redox mechanisms for activation of latent transforming growth factor-beta 1. Mol Endocrinol (1996) 10:1077-83. doi:10.1210/ me.10.9.1077

51. Nishioka A, Ogawa Y, Mima T, Jin YJ, Sonobe H, Kariya S, et al. Histopathologic amelioration of fibroproliferative change in rat irradiated lung using soluble transforming growth factor-beta (TGF-beta) receptor mediated by adenoviral vector. Int J Radiat Oncol Biol Phys (2004) 58(4):1235-41. doi:10.1016/j. ijrobp.2003.11.006

52. Novakova-Jiresovaa A, van Gameren MM, Coppes RP, Kampinga HH, Groen HJ. Transforming growth factor-b plasma dynamics and postirradiation lung injury in lung cancer patients. Radiother Oncol (2004) 71: 183-9. doi:10.1016/j.radonc.2004.01.019

53. Anscher MS, Peters WP, Reisenbichler H, Petros WP, Jirtle RL. Transforming growth factor beta as a predictor of liver and lung fibrosis after autologous bone marrow transplantation for advanced breast cancer. $N$ Engl J Med (1993) 328:1592-8. doi:10.1056/NEJM199306033282203

54. Rube CE, Rodemann HP, Rube C. The relevance of cytokines in the radiation-induced lung reaction. Experimental basis and clinical significance. Strahlenther Onkol (2004) 180(9):541-9. doi:10.1007/s00066-004-1279-1

55. Luo Y, Wang M, Pang Z, Jiang F, Chen J, Zhang J. Locally instilled tumor necrosis factor alpha antisense oligonucleotide contributes to inhibition of TH 2-driven pulmonary fibrosis via induced CD4+ CD25+ Foxp3+ regulatory T cells. J Gene Med (2013) 15(11-12):441-52. doi:10.1002/jgm.2750

56. Wolf J, Rose-John S, Garbers C. Interleukin-6 and its receptors: a highly regulated and dynamic system. Cytokine (2014) 70:11-20. doi:10.1016/j. cyto.2014.05.024

57. Scheller J, Chalaris A, Schmidt-Arras D, Rose-John S. The pro- and anti-inflammatory properties of the cytokine interleukin-6. Biochim Biophys Acta (2011) 1813(5):878-88. doi:10.1016/j.bbamcr.2011.01.034

58. Chen Y, Williams J, Ding I, Hernady E, Liu W, Smudzin T, et al. Radiation pneumonitis and early circulatory cytokine markers. Semin Radiat Oncol (2002) 12(1 Suppl 1):22-33. doi:10.1053/srao.2002.31360

59. Li B, Chen SH, Lu HJ, Tan Y. Predictive values of TNF- $\alpha$, IL-6, IL-10 for radiation pneumonitis. Int J Radiat Res (2016) 14(3):173-9. doi:10.18869/ acadpub.ijrr.14.3.173

60. Abdollahi A, Li M, Huber PE. Inhibition of platelet-derived growth factor signalling attenuates pulmonary fibrosis. J Exp Med (2005) 201(6):925-35. doi:10.1084/jem.20041393

61. Kong FM, Ten Haken R, Eisbruch A, Lawrence TS. Non-small cell lung cancer therapy-related pulmonary toxicity: an update on radiation pneumonitis and fibrosis. Semin Oncol (2005) 32(2 Suppl 3):S42-54. doi:10.1053/j. seminoncol.2005.03.009

62. Kong FM, Ten Haken RK, Schipper MJ, Sullivan MA, Chen M, Lopez C, et al. High-dose radiation improved local tumor control and overall survival in patients with inoperable/unresectable non-small-cell lung cancer: long term results of a radiation dose escalation study. Int J Radiat Oncol Biol Phys (2005) 63:324-33. doi:10.1016/j.ijrobp.2005.02.010

63. Kong FM, Pan C, Eisbruch A, Ten Haken RK. Physical models and simpler dosimetric descriptors of radiation late toxicity. Semin Radiat Oncol (2007) 17:108-20. doi:10.1016/j.semradonc.2006.11.007

64. Kong FM, Hayman JA, Griffith KA, Kalemkerian GP, Arenberg D, Lyons S, et al. Final toxicity results of a radiation-dose escalation study in patients with non-small-cell lung cancer (NSCLC): predictors for radiation pneumonitis and fibrosis. Int J Radiat Oncol Biol Phys (2006) 65:1075-86. doi:10.1016/j. ijrobp.2006.01.051

65. Robnett TJ, Machtay M, Vines EF, McKenna MG, Algazy KM, McKenna WG. Factors predicting severe radiation pneumonitis in patients receiving definitive chemoradiation for lung cancer. Int J Radiat Oncol Biol Phys (2000) 48:89-94. doi:10.1016/S0360-3016(00)00648-9

66. Graham MV, Purdy JA, Emami B, Harms W, Bosch W, Lockett MA, et al. Clinical dose-volume histogram analysis for pneumonitis after 3D treatment 
for non-small cell lung cancer (NSCLC). Int J Radiat Oncol Biol Phys (1999) 45(2):323-9. doi:10.1016/S0360-3016(99)00183-2

67. Billiet C, Peeters S, De Ruysscher D. Focus on treatment complications and optimal management: radiation oncology. Transl Lung Cancer Res (2014) 3(3):187-91. doi:10.3978/j.issn.2218-6751.2014.06.08

68. Fu XL, Huang H, Bentel G, Clough R, Jirtle RL, Kong FM, et al. Predicting the risk of symptomatic radiation-induced lung injury using both the physical and biologic parameters $\mathrm{V}(30)$ and transforming growth factor beta. Int J Radiat Oncol Biol Phys (2001) 50:899-908. doi:10.1016/S0360-3016(01) 01524-3

69. Dehing-Oberije C, De Ruysscher D, van Baardwijk A, Yu S, Rao B, Lambin P. The importance of patient characteristics for the prediction of radiationinduced lung toxicity. Radiother Oncol (2009) 91:421-6. doi:10.1016/j.radonc. 2008.12.002

70. Fay M, Tan A, Fisher R, Mac Manus M, Wirth A, Ball D. Dose-volume histogram analysis as predictor of radiation pneumonitis in primary lung cancer patients treated with radiotherapy. Int J Radiat Oncol Biol Phys (2005) 61:1355-63. doi:10.1016/j.ijrobp.2004.08.025

71. Wang S, Liao Z, Wei X, Liu HH, Tucker SL, Hu CS, et al. Analysis of clini$\mathrm{cal}$ and dosimetric factors associated with treatment-related pneumonitis (TRP) in patients with non-small-cell lung cancer (NSCLC) treated with concurrent chemotherapy and three-dimensional conformal radiotherapy (3D-CRT). Int J Radiat Oncol Biol Phys (2006) 66:1399-407. doi:10.1016/j. ijrobp.2006.07.1337

72. Jenkins $P$, Watts J. An improved model for predicting radiation pneumonitis incorporating clinical and dosimetric variables. Int J Radiat Oncol Biol Phys (2011) 80(4):1023-9. doi:10.1016/j.jirobp.2010.03.058

73. Yorke ED, Jackson A, Rosenzweig KE, Braban L, Leibel SA, Ling CC. Correlation of dosimetric factors and radiation pneumonitis for non-smallcell lung cancer patients in a recently completed dose escalation study. Int J Radiat Oncol Biol Phys (2005) 63:672-82. doi:10.1016/j.ijrobp.2005. 03.026

74. Paun A, Haston CK. Genomic and genome-wide association of susceptibility to radiation-induced fibrotic lung disease in mice. Radiother Oncol (2012) 105:350-7. doi:10.1016/j.radonc.2012.08.004

75. Kobayashi J, Kitramura S. KL-6: a serum marker for interstitial pneumonia. Chest (1995) 108(2):311-5. doi:10.1378/chest.108.2.311

76. Goto K, Kodama T, Sekine I, Kakinuma R, Kubota K, Hojo F, et al. Serum levels of KL-6 are useful biomarkers for severe radiation pneumonitis. Lung Cancer (2001) 34:141-8. doi:10.1016/S0169-5002(01)00215-X

77. Marsh JC, Wendt JA, Walker A, Turian JV, Kiel K. Clinical predictive factors for radiation pneumonitis and pulmonary fibrosis during split course concurrent chemoirradiation for locally advanced non-small cell lung cancer. J Cancer Ther Res (2012) 1:6. doi:10.7243/2049-7962-1-6

78. Marks LB, Munley MT, Bentel GC, Zhou SM, Hollis D, Scarfone C, et al. Physical and biological predictors of changes in wholelung function following thoracic irradiation. Int J Radiat Oncol Biol Phys (1997) 39(3):563-70. doi:10.1016/S0360-3016(97)00343-X

79. Jagannath KP, Lokesh V, Thejaswini B, Ajay GV, Ashalatha D, Bhaumik S, et al. Study of early radiation pneumonitis in carcinoma breast and lung treated with radiotherapy. Nat J Med Res (2013) 3(3):236-40.

80. Wang H, Liao Z, Zhuang Y, Xu T, Nguyen QN, Levy LB, et al. Do angiotensin-converting enzyme inhibitors reduce the risk of symptomatic radiation pneumonitis in patients with non-small cell lung cancer after definitive radiation therapy? Analysis of a single-institution database. Int J Radiat Oncol Biol Phys (2013) 87(5):1071-7. doi:10.1016/j. ijrobp.2013.08.033

81. Wang YS, Chang HJ, Chang YC, Huang SC, Ko HL, Chang CC, et al. Serum amuloid as a predictive marker for radiation pneumonitis in lung cancer patients. Int J Radiat Oncol Biol Phys (2013) 85(3):791-7. doi:10.1016/j. ijrobp.2012.06.018

82. American Thoracic Society/European Respiratory Society International Multidisciplinary Consensus Classification of the Idiopathic interstitial Pneumonias. This joint statement of the American Thoracic Society (ATS), and the European Respiratory Society (ERS) was adopted by the ATS board of directors, June 2001 and by the ERS Executive Committee, June 2001. Am J Respir Crit Care Med (2002) 165:277-304. doi:10.1164/ajrccm.165.2.ats01
83. Bradley J, Movsas B. Radiation pneumonitis and esophagitis in thoracic irradiation. In: Small W, Woloschak GE, editors. Radiation Toxicity: A Pracitical Guide. New York, NY: Springer Science Media Business, Inc. (2006). p. 43-52.

84. Day RM, Barshishat-Kupper M, Mog SR, McCart EA, Prasanna PG, Davis TA, et al. Genistein protects against biomarkers of delayed lung sequelae in mice surviving high-dose total body irradiation. J Radiat Res (2008) 49:361-72. doi:10.1269/jrr.07121

85. Ozturk B, Egehan I, Atavci S, Kitapci M. Pentoxifylline in prevention of radiation-induced lung toxicity in patients with breast and lung cancer: a double-blind randomized trial. Int J Radiat Oncol Biol Phys (2004) 58(1): 213-9. doi:10.1016/S0360-3016(03)01444-5

86. Agrawal S. Late effects of cancer treatment in breast cancer survivors. South Asian J Cancer (2014) 3:112-5. doi:10.4103/2278-330X.130445

87. Keller SM, Adak S, Wagner H, Herskovic A, Komaki R, Brooks BJ, et al. A randomized trial of postoperative adjuvant therapy in patients with completely resected stage II or IIIA non-small-cell lung cancer. Eastern Cooperative Oncology Group. NEngl J Med (2000) 343:1217-22. doi:10.1056/ NEJM200010263431703

88. Bradley JD, Paulus R, Graham MV, Ettinger DS, Johnstone DW, Pilepich MV, et al. Phase II trial of postoperative adjuvant paclitaxel/carboplatin and thoracic radiotherapy in resected stage II and IIIA non-small-cell lung cancer. Promising long-term results of the Radiation Therapy Oncology Group - RTOG 9705. JClin Oncol (2005) 23:3480-7. doi:10.1200/JCO. 2005.12.120

89. Feigenberg SJ, Hanlon AL, Langer C, Goldberg M, Nicolaou N, Millenson M, et al. A phase II study of concurrent carboplatin and paclitaxel and thoracic radiotherapy for completely nresected stage II and IIIA nonsmall cell lung cancer. J Thorac Oncol (2007) 2:287-92. doi:10.1097/01. JTO.0000263710.54073.b3

90. Curran WJ Jr, Paulus R, Langer CJ, Komaki R, Lee JS, Hauser S, et al. Sequential vs. concurrent chemoradiation for stage III non-small cell lung cancer: randomized phase III trial RTOG 9410. J Natl Cancer Inst (2011) 103:1452-60. doi:10.1093/jnci/djr325

91. Onishi H, Kuriyama K, Yamaguchi M, Komiyama T, Tanaka S, Araki T, et al. Concurrent two-dimensional radiotherapy and weekly docetaxel in the treatment of stage III non-small cell lung cancer: a good local response but no good survival due to radiation pneumonitis. Lung Cancer (2003) 40:79-84. doi:10.1016/S0169-5002(02)00532-9

92. Zheng W, Gao ZH, Wu LN. Clinical observation on treatment of radiative pneumonia in patients with lung cancer by integrative Chinese and Western medicine. Zhongguo Zhong Xi Yi Jie He Za Zhi (2007) 27:1121-3.

93. Paun A, Fox J, Balloy V, Chignard M, Qureshi ST, Haston CK. Combined Tlr2 and Tlr4 deficiency increases radiation-induced pulmonary fibrosis in mice. Int J Radiat Oncol Biol Phys (2010) 77(4):1198-205. doi:10.1016/j. ijrobp.2009.12.065

94. Anscher MS, Thrasher B, Zgonjanin L, Rabbani ZN, Corbley MJ, Fu K, et al. Small molecular inhibitor of transforming growth factor-beta protects against development of radiation-induced lung injury. Int $J$ Radiat Oncol Biol Phys (2008) 71:829-37. doi:10.1016/j.ijrobp.2008.02.046

95. Niu X, Li H, Chen Z, Liu Y, Kan M, Zhou D, et al. A study of ethnic differences in TGF $\beta 1$ gene polymorphisms and effects on the risk of radiation pneumonitis in non-small-cell lung cancer. J Thorac Oncol (2012) 7:1668-75. doi:10.1097/JTO.0b013e318267cf5b

96. Voets AM, Oberije C, Struijk RB, Reymen B, De Ruyck K, Thierens H, et al. No association between TGF- $\beta 1$ polymorphisms and radiation-induced lung toxicity in a European cohort of lung cancer patients. Radiother Oncol (2012) 105:296-8. doi:10.1016/j.radonc.2012.09.016

97. Wang Y, Wang X, Wang X, Zhang D, Jiang S. Effect of transforming growth factor- $\beta 1869 \mathrm{C} / \mathrm{T}$ polymorphism and radiation pneumonitis. Int J Clin Exp Pathol (2015) 8(3):2835-9.

98. Flechsig P, Dadrich M, Bickelhaupt S, Jenne J, Hauser K, Timke C, et al. LY2109761 attenuates radiation-induced pulmonary murine fibrosis via reversal of TGFbeta and BMP-associated proinflammatory and proangiogenic signals. Clin Cancer Res (2012) 18:3616-3127. doi:10.1158/1078-0432. CCR-11-2855

99. Dennler S, Itoh S, Vivien D, ten Dijke P, Huet S, Gauthier JM. Direct binding of Smad3 and Smad4 to critical TGF beta-inducible elements in the promoter 
of human plasminogen activator inhibitor type 1 gene. EMBO J (1998) 17:3091-100. doi:10.1093/emboj/17.11.3091

100. Hakenjos L, Bamberg M, Rodemann HP. TGF-beta1-mediated alterations of rat lung fibroblast differentiation resulting in the radiation induced fibrotic phenotype. Int J Radiat Biol (2000) 76:503-9. doi:10.1080/ 095530000138501

101. Wang LH, Liu JS, Ning WB, Yuan QJ, Zhang FF, Peng ZZ, et al. Fluorofenidone attenuates diabetic nephropathy and kidney fibrosis in $\mathrm{db} / \mathrm{db}$ mice. Pharmacology (2011) 88:88-99. doi:10.1159/000329419

102. Chen LX, Yang K, Sun M, Chen Q, Wang ZH, Hu GY, et al. Fluorofenidone inhibits transforming growth factor-betal-induced cardiac myofibroblast differentiation. Pharmazie (2012) 67:452-6. doi:10.1691/ph.2012.1748

103. Giridhar P, Mallick S, Rath GK, Julka PK. Radiation induced lung injury: prediction, assessment and management. Asian Pac J Cancer Prev (2015) 16(7):2613-7. doi:10.7314/APJCP.2015.16.7.2613

104. Li Y, Song LW, Peng RY, Wang DW, Jin MH, Gao YB, et al. Effects of SB203580 and WP631 on Smad signal transduction pathway in lung fibroblasts after irradiation. Chinese J Cancer (2008) 27:26-9.

105. Sekine I, Sumi M, Ito Y, Nokihara H, Yamamoto N, Kunitoh H, et al. Retrospective analysis of steroid therapy for radiation-induced lung injury in lung cancer patients. Radiother Oncol (2006) 80:93-7. doi:10.1016/j. radonc.2006.06.007

106. Fujino N, Kubo H, Suzuki T, He M, Suzuki T, Yamada M, et al. Administration of a specific inhibitor of neutrophil elastase attenuates pulmonary fibrosis after acute lung injury in mice. Exp Lung Res (2012) 38:28-36. doi:10.3109/ 01902148.2011 .633306

107. McLnerney DP, Bullimore J. Reactivation of radiation pneumonitis by adriamycin. Br J Radiol (1977) 50:224-7. doi:10.1259/0007-1285-50-591-224

108. Ma LD, Taylor GA, Wharam MD, Wiley JM. "Recall" pneumonitis: adriamycin potentiation of radiation pneumonitis in two children. Radiology (1993) 187:465-7. doi:10.1148/radiology.187.2.8475291

109. Schweitzer VG, Juillard GJ, Bajada CL, Parker RG. Radiation recall dermatitis and pneumonitis in a patient treated with paclitaxel. Cancer (1995) 76:1069-72. doi:10.1002/1097-0142(19950915)76:6<1069::AIDCNCR2820760623>3.0.CO;2-7

110. Hill AB, Tattersall SF. Recall of radiation pneumonitis after intrapleural administration of doxorubicin. Med J Aust (1983) 1:39-40.

111. Gauter-Fleckenstein B, Fleckenstein K, Owzar K, Jiang C, Rebouças JS, Batinic-Haberle I, et al. Early and late administration of MnTE-2-PyP5+ in mitigation and treatment of radiation-induced lung damage. Free Radic Biol Med (2010) 48:1034-43. doi:10.1016/j.freeradbiomed.2010.01.020

112. Para AE, Bezjak A, Yeung IW, Dyk, Hill RP. Effects of genistein following fractionated lung irradiation in mice. Radiother Oncol (2009) 92:500-10. doi:10.1016/j.radonc.2009.04.005

113. Su Q, Wang D, Yuan B, Liu F, Lei Y, Li S. Effects of proton pump inhibitors on lung cancer precise radiotherapy-induced radiation pneumonitis. Cell Biochem Biophys (2014) 70:1113-7. doi:10.1007/s12013-014-0030-5

114. Okunieff P, Augustine E, Hicks JE, Cornelison TL, Altemus RM, Naydich BG, et al. Pentoxifylline in the treatment of radiation-induced fibrosis. Clin Oncol (2004) 22:2207-13. doi:10.1200/JCO.2004.09.101

115. Hunter NR, Valdecanas D, Liao Z, Milas L, Thames HD, Mason KA. Mitigation and treatment of radiation-induced thoracic injury with a cyclooxygenase-2 inhibitor, celecoxib. Int J Radiat Oncol Biol Phys (2013) 85(2):472-6. doi:10.1016/j.jijrobp.2012.04.025

116. Katoch O, Dwarakanath BS, Agrawala PK. HDAC inhibitors: applications in oncology and beyond. HOAJ Biol (2013) 2(2). doi:10.7243/2050-0874-2-2

117. Katoch O, Kumar A, Adhikari JS, Dwarakanath BS, Agrawala PK. Sulforaphane mitigates genotoxicity induced by radiation and anticancer drugs in human lymphocytes. Mutat Res (2013) 758:29-34. doi:10.1016/j. mrgentox.2013.08.009

118. Tiwari M, Dixit B, Parvez S, Agrawala PK. EGCG, a tea polyphenol, as a potential mitigator of hematopoietic radiation injury in mice. Biomed Pharmacother (2017) 88:203-9. doi:10.1016/j.biopha.2016.12.129

119. Katoch O, Khan G, Dwarakanath B, Agrawala P. Mitigation of hematopoietic radiation-injury by diallyl sulphide. J Environ Pathol Toxicol Oncol (2012) 31(4):357-65. doi:10.1615/JEnvironPatholToxicolOncol.2013005833

120. Agrawala PK, Katoch O. Radiomitigating potential of sulforaphane, a constituent of broccoli. In: Bernhard J, editor. Broccoli: Cultivation, Nutritional Properties and Effects on Health. New York, NY: Nova Publishers (2013). p. $145-60$.

121. Park MJ, Sohrabji F. The histone deacetylase inhibitor, sodium butyrate, exhibits neuroprotective effects for ischemic stroke in middle-aged female rats. J Neuroinflammation (2016) 13(1):300. doi:10.1186/ s12974-016-0765-6

122. Losson H, Schnekenburger M, Dicato M, Diederich M. Natural compound histone deacetylase inhibitors (HDACi): synergy with inflammatory signaling pathway modulators and clinical applications in cancer. Molecules (2016) 21(11):1608. doi:10.3390/molecules21111608

123. Hu L, Yu Y, Huang H, Fan H, Hu L, Yin C, et al. Epigenetic regulation of interleukin 6 by histone acetylation in macrophages and its role in paraquat-induced pulmonary fibrosis. Front Immunol (2017) 7:696. doi:10.3389/ fimmu.2016.00696

124. Sathishkumar C, Prabu P, Balakumar M, Lenin R, Prabhu D, Anjana RM, et al. Augmentation of histone deacetylase 3 (HDAC3) epigenetic signature at the interface of proinflammation and insulin resistance in patients with type 2 diabetes. Clin Epigenetics (2016) 24(8):125. doi:10.1186/s13148016-0293-3

125. Li LF, Lee CS, Lin CW, Chen NH, Chuang LP, Hung CY, et al. Trichostatin A attenuates ventilation-augmented epithelial-mesenchymal transition in mice with bleomycin-induced acute lung injury by suppressing the Akt pathway. PLoS One (2017) 12(2):e0172571. doi:10.1371/journal.pone. 0172571

Conflict of Interest Statement: The authors declare that the research was conducted in the absence of any commercial or financial relationships that could be construed as a potential conflict of interest.

Copyright (c) 2017 Kainthola, Haritwal, Tiwari, Gupta, Parvez, Tiwari, Prakash and Agrawala. This is an open-access article distributed under the terms of the Creative Commons Attribution License (CC BY). The use, distribution or reproduction in other forums is permitted, provided the original author(s) or licensor are credited and that the original publication in this journal is cited, in accordance with accepted academic practice. No use, distribution or reproduction is permitted which does not comply with these terms. 